Supporting Information for

\title{
The Dynamics of Copper-Containing Porous Organic Framework Catalysts Reveal Catalytic Behavior Controlled by Polymer Structure
}

\author{
Zhenwei $\mathrm{Wu}^{\dagger}$, Xu Zhang ${ }^{\dagger,}$, Emmett D. Goodman ${ }^{\dagger}$, Weixin Huang ${ }^{\dagger}$, Andrew Riscoe ${ }^{\dagger}$, \\ Sara Yacob $^{\perp}$, Matteo Cargnello
}

${ }^{\dagger}$ Department of Chemical Engineering and SUNCAT Center for Interface Science and Catalysis, Stanford University, Stanford, California 94305, United States

${ }^{*}$ School of Materials Science and Engineering, Tsinghua University, Beijing 10084, China ${ }^{\perp}$ ExxonMobil Research and Engineering, Annandale, New Jersey 08801, United States

${ }^{*}$ Corresponding author: mcargnello@stanford.edu 


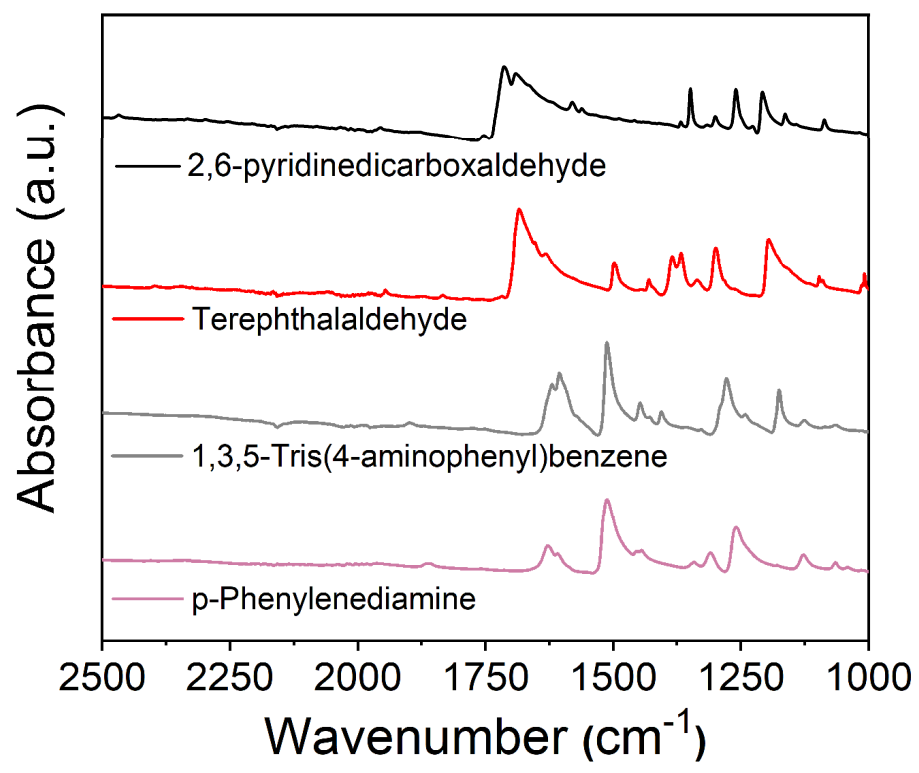

Fig. S1. The FTIR spectra of the aldehyde and amine monomers used in the IPOF syntheses. 


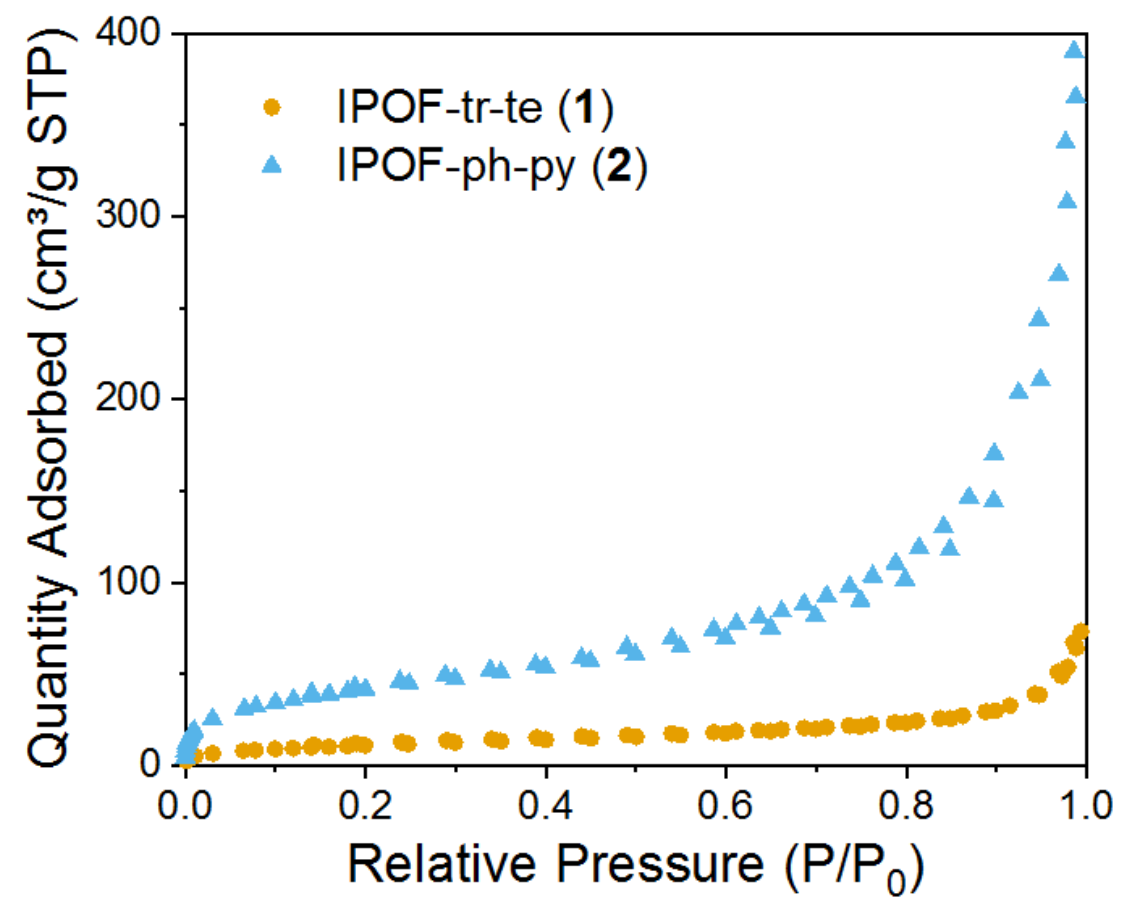

Fig. S2. $\mathrm{N}_{2}$ physisorption isotherm of IPOF-tr-te (1) and IPOF-ph-py (2). 

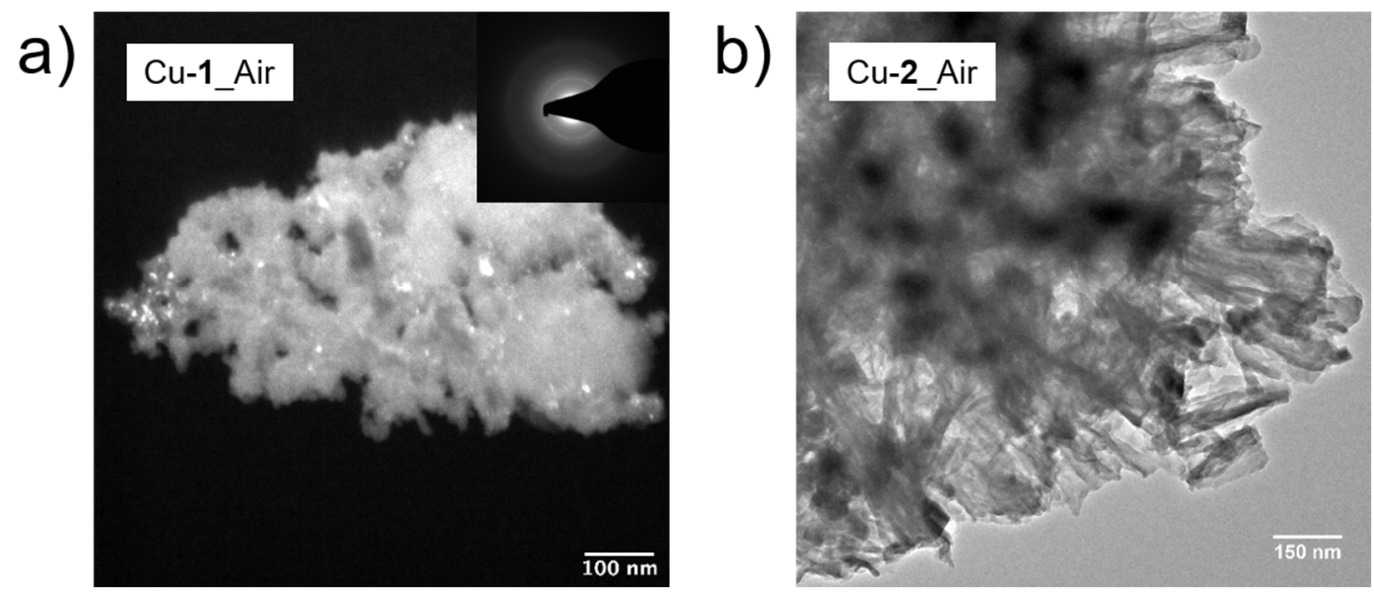

Fig. S3. a) TEM electron diffraction imaging and pattern of $\mathrm{Cu}-\mathbf{1} \_$Air, and b) TEM image of $\mathrm{Cu}-$ 2_Air. 

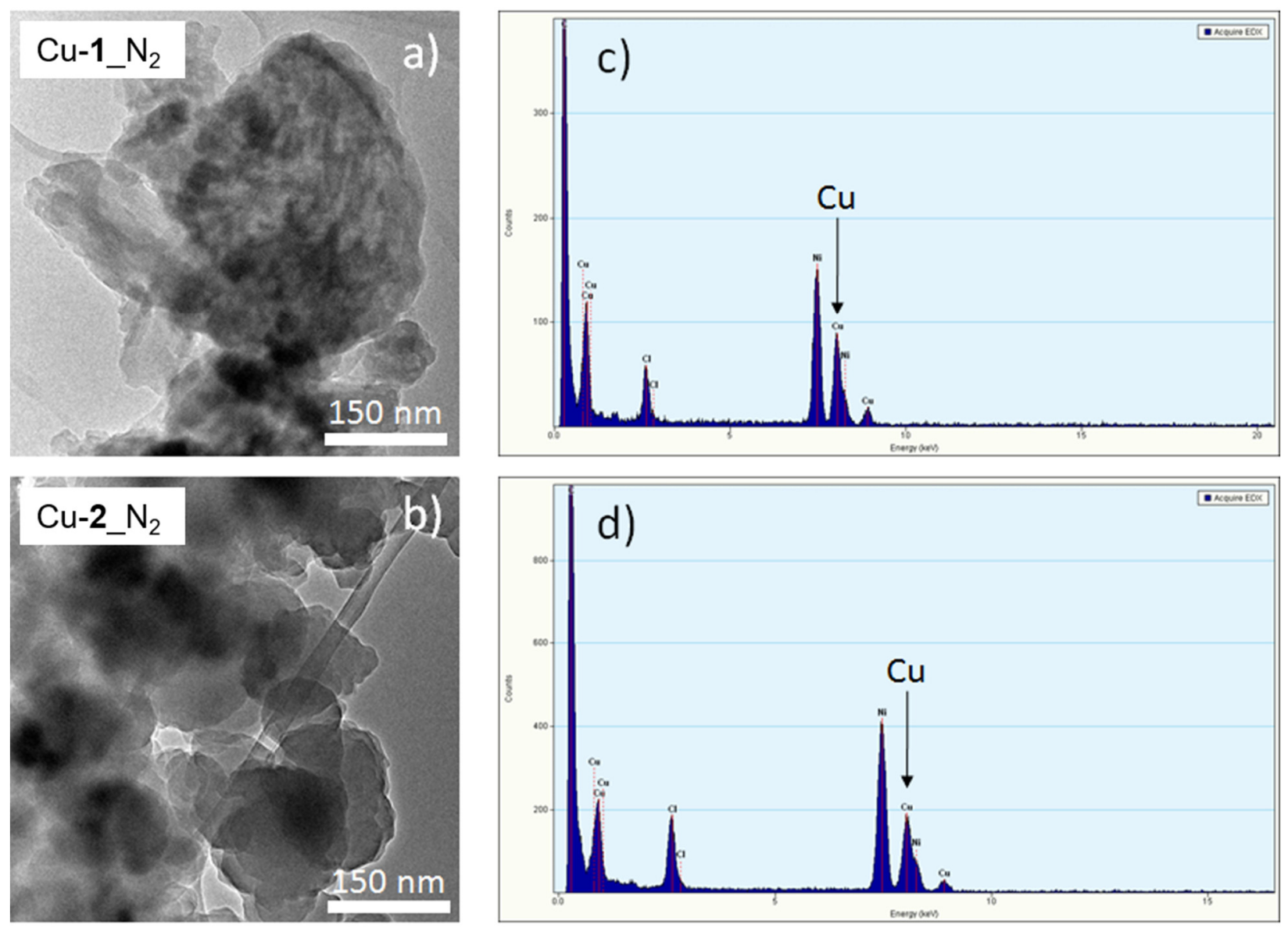

Fig. S4. TEM images (a, b) and EDS analysis (c, d) of samples $\mathrm{Cu}-\mathbf{1} \_\mathrm{N}_{2}$ and $\mathrm{Cu}-\mathbf{2} \_\mathrm{N}_{2}$, respectively. 


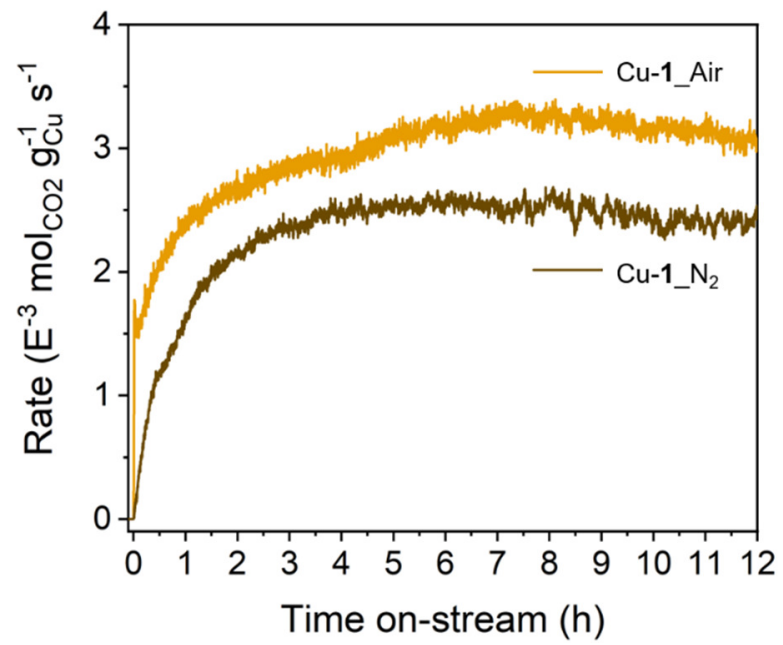

Fig. S5. CO oxidation reaction rate versus time on stream for $\mathrm{Cu}-\mathbf{1} \_\mathrm{N}_{2}$ and $\mathrm{Cu}-\mathbf{1} \_$Air with a reaction mixture containing $\mathrm{CO}: \mathrm{O}_{2}=1$ for 12 hours. 
Cu-1 Air

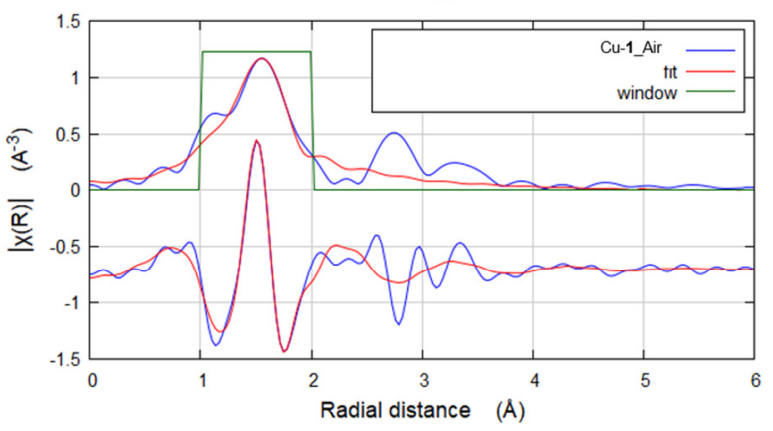

Cu-2 Air

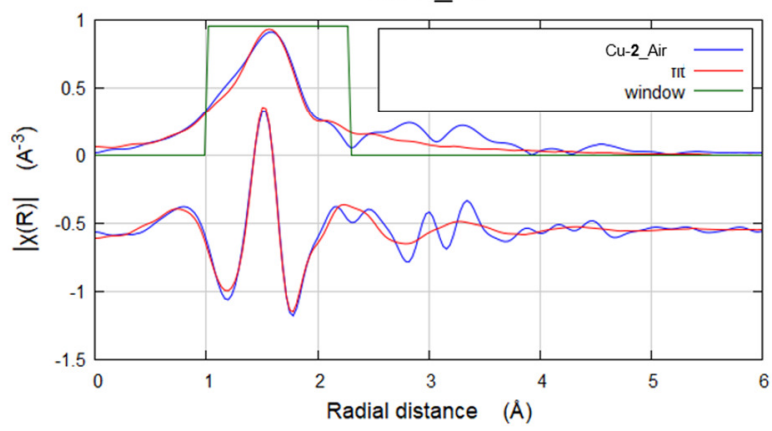

$\mathrm{Cu}-1 \_\mathrm{N}_{2}$

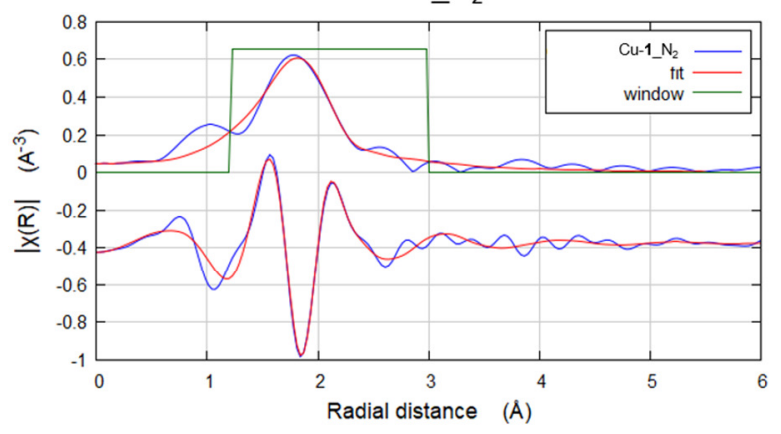

$\mathrm{Cu}-2 \mathrm{~N}_{2}$

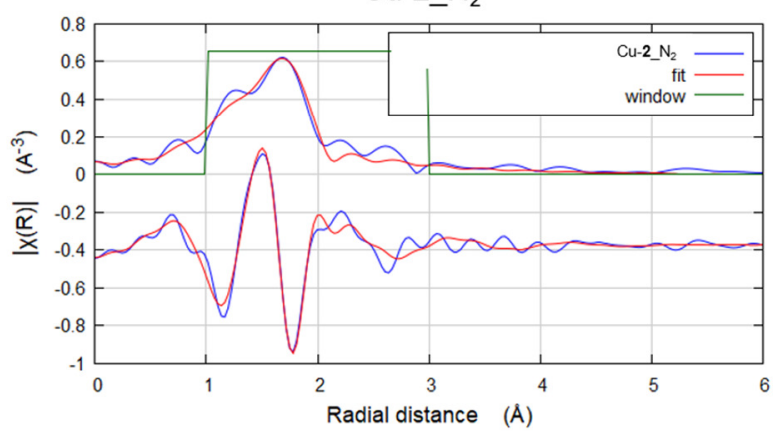

Fig. S6. The real part and magnitude of Fourier transform of $k^{2}$ weighted chi(k) of EXAFS of the $\mathrm{Cu}-1$ _Air, $\mathrm{Cu}-1 \_\mathrm{N}_{2}, \mathrm{Cu}-\mathbf{2} \_$Air, $\mathrm{Cu}-\mathbf{2} \_\mathrm{N}_{2}$. 


\section{Cu-2_Air}
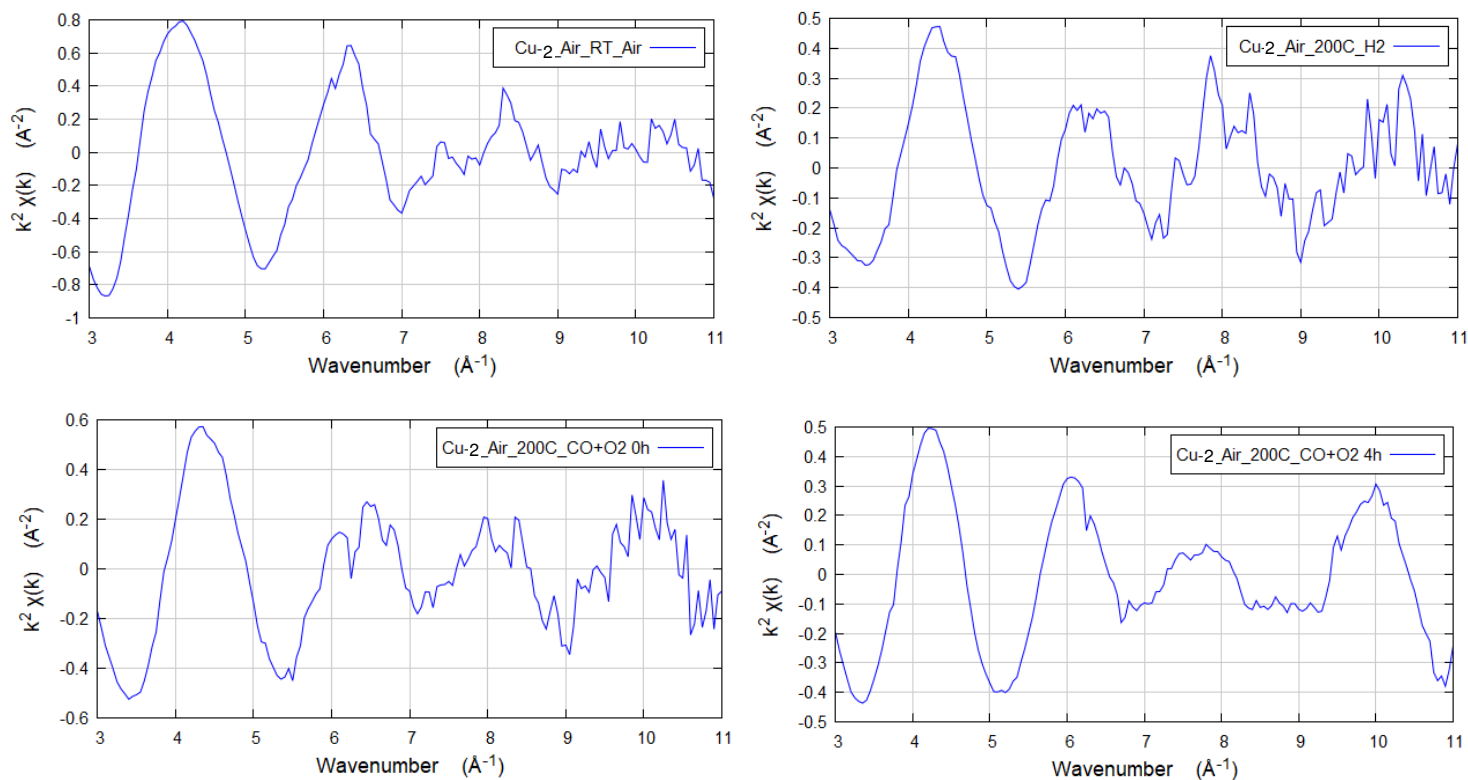

\section{Cu-2_N 2}
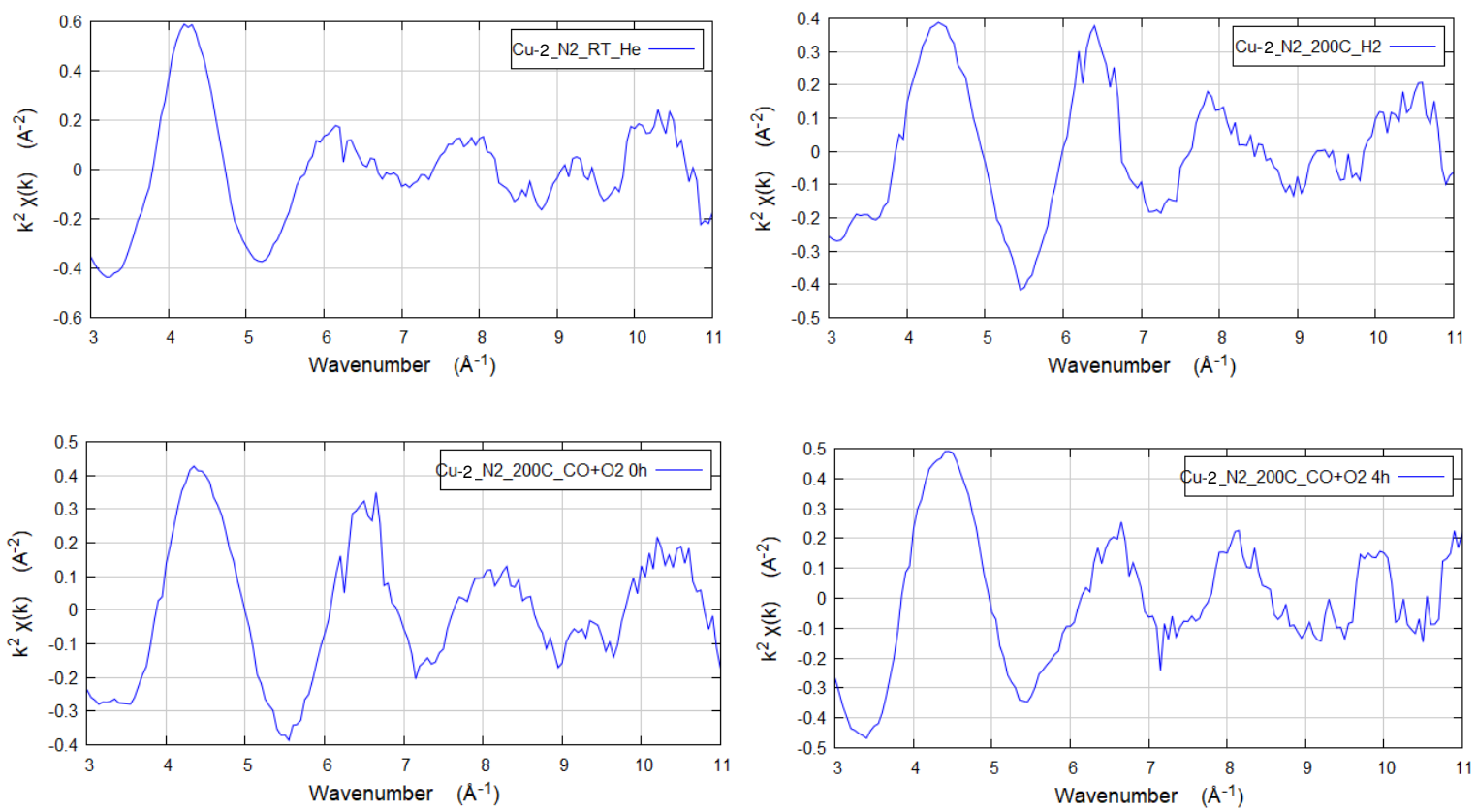


\section{Cu-1_Air}
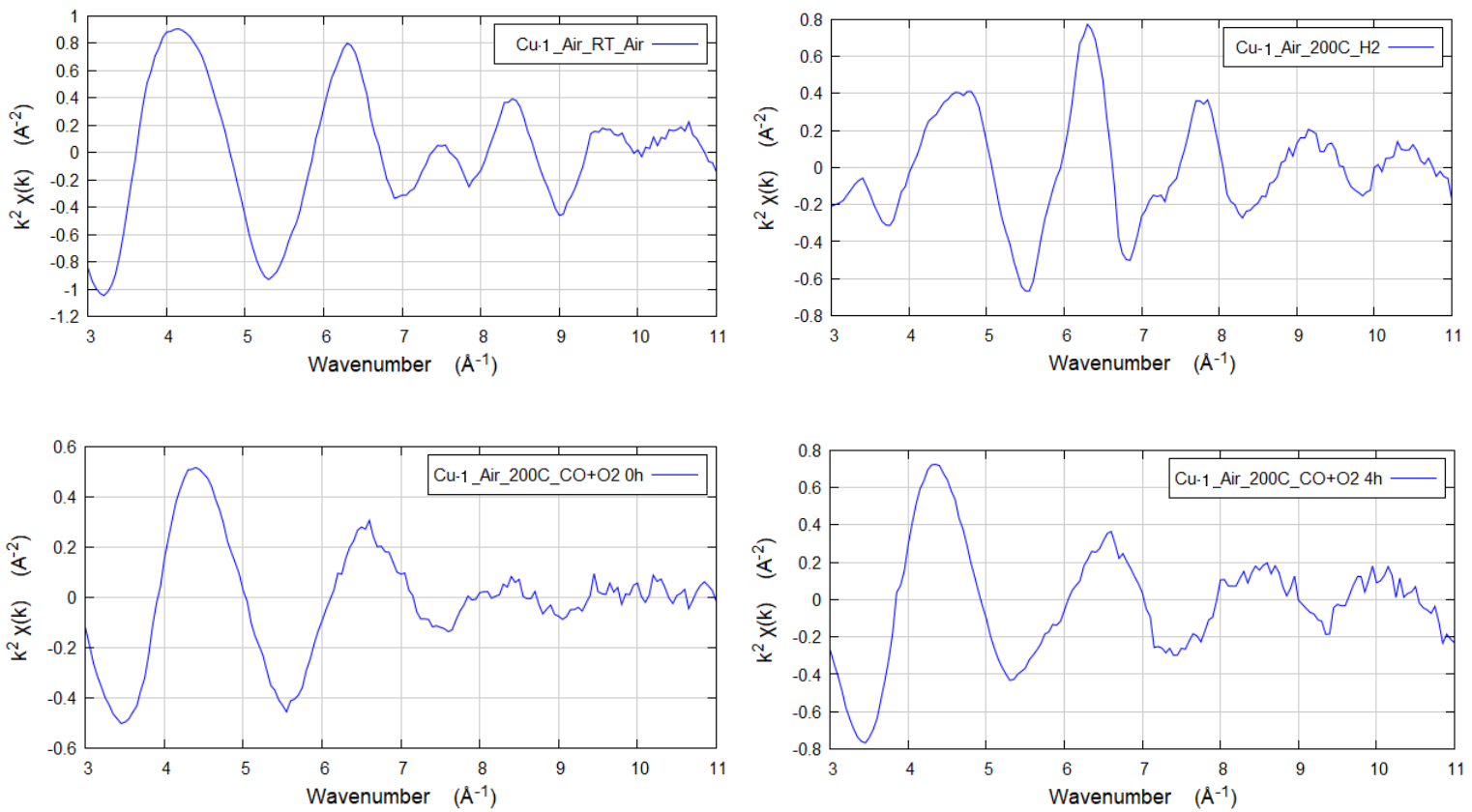

\section{Cu-1_N 2}
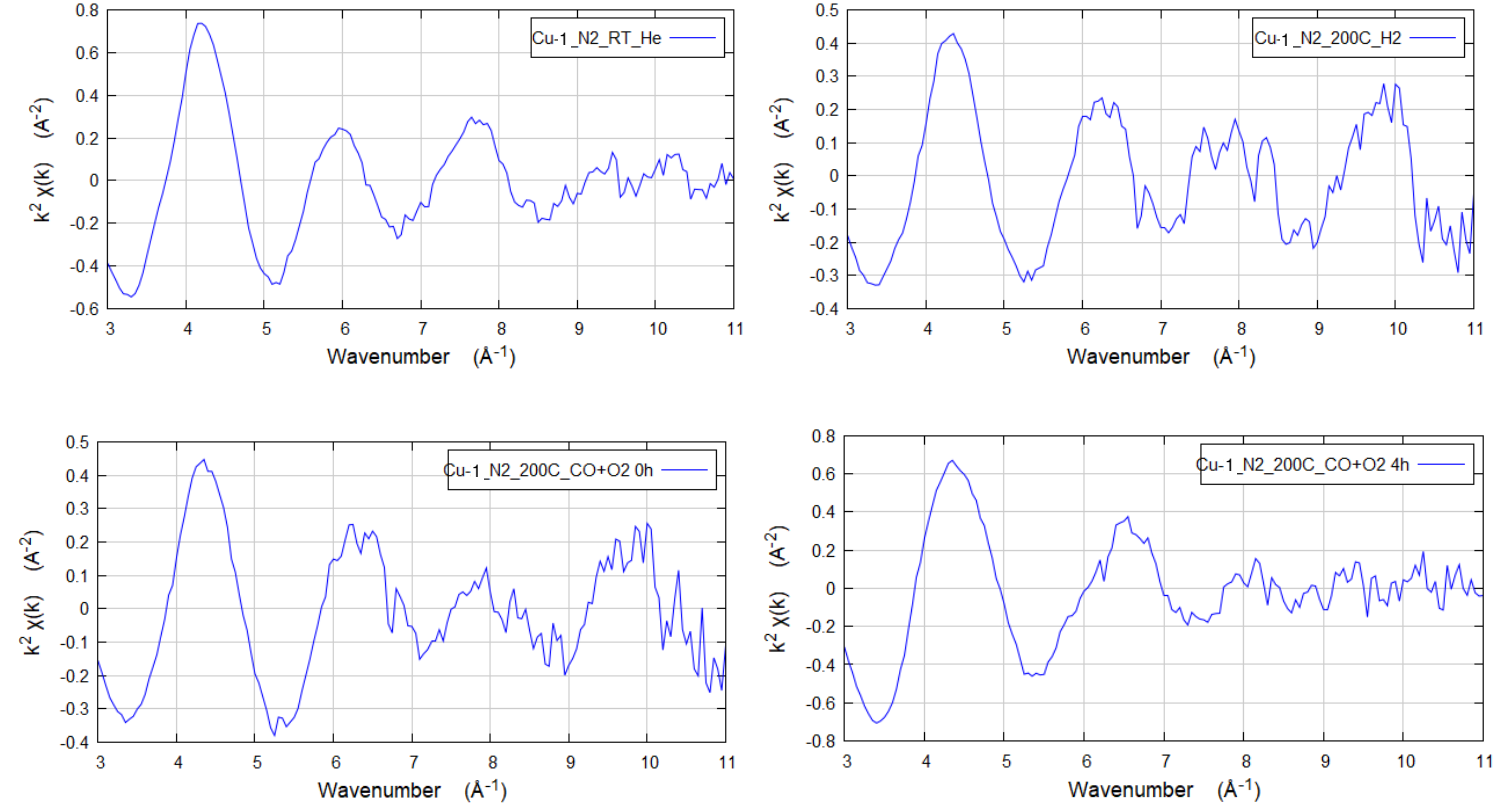

Fig. S7. $\mathrm{k}^{2}$ weighted chi(k) of in situ EXAFS of the $\mathrm{Cu}-\mathrm{IPOF}$ catalysts measured at room temperature in air, $200{ }^{\circ} \mathrm{C}$ in $\mathrm{H}_{2}$ after reduction for 1 hour, $20{ }^{\circ} \mathrm{C}$ in $\mathrm{CO}$ and $\mathrm{O}_{2}(1: 1)$. 

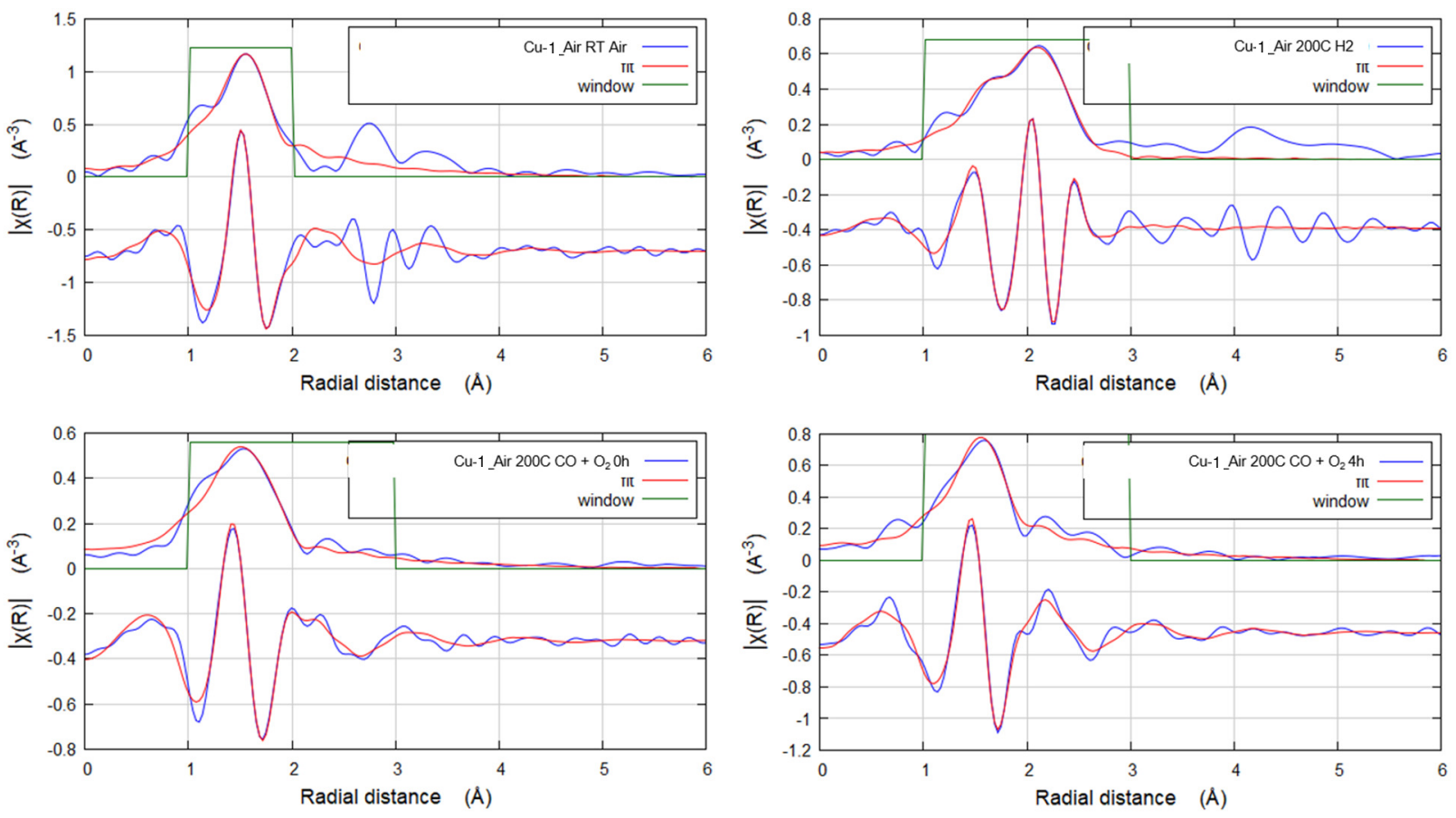

Fig. S8. The real part and magnitude of Fourier transform of $\mathrm{k}^{2}$ weighted chi(k) of in situ EXAFS of the $\mathrm{Cu}$-1_Air catalysts measured at room temperature in air, $200{ }^{\circ} \mathrm{C}$ in $\mathrm{H}_{2}$ after reduction for 1 hour, $200{ }^{\circ} \mathrm{C}$ in $\mathrm{CO}$ and $\mathrm{O}_{2}$ (1:1) and corresponding fits. 

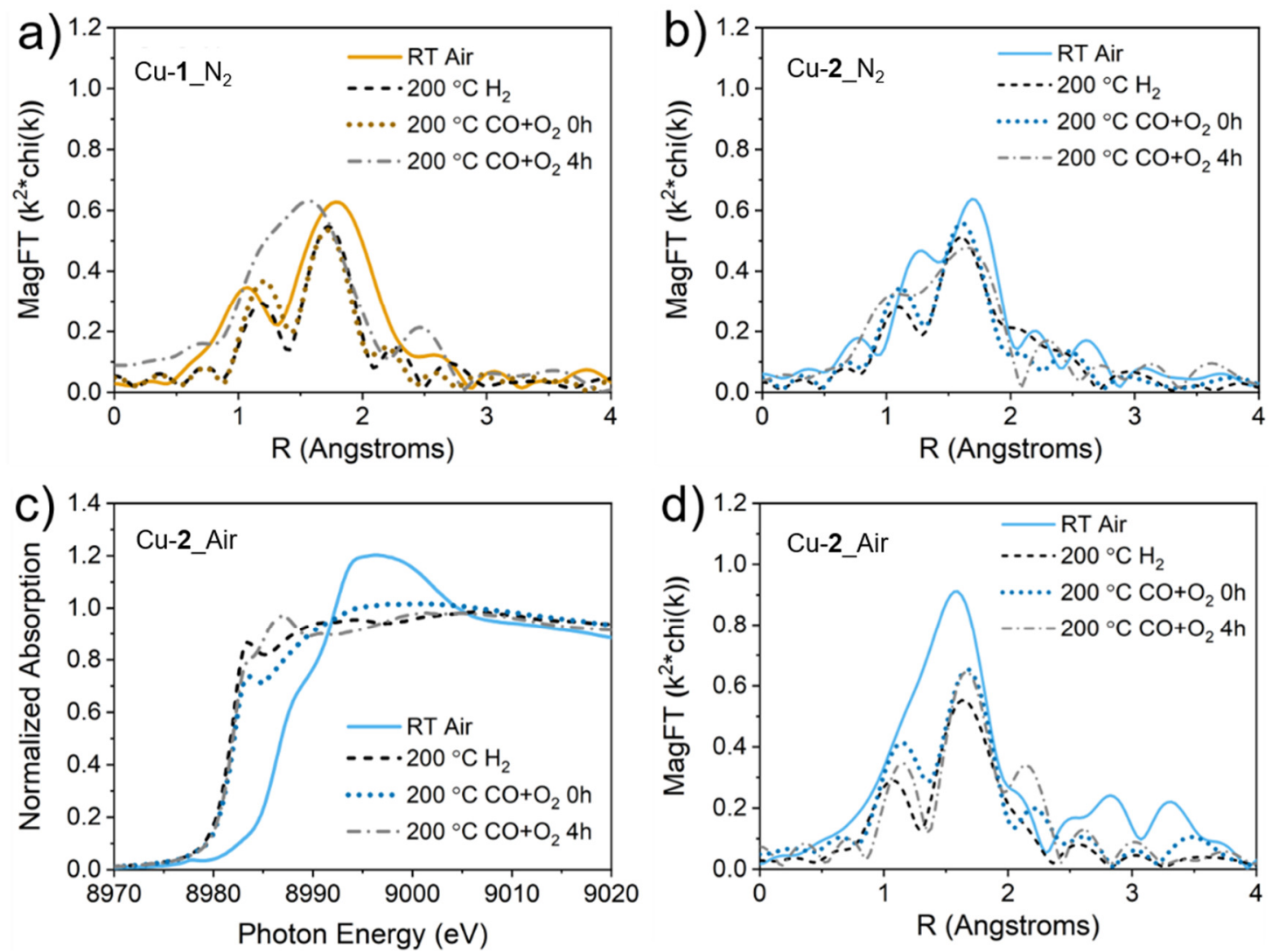

Fig. S9. a) magnitude of the Fourier transform of $\mathrm{k}^{2}$-weighted $\mathrm{Cu} \mathrm{K}$ edge EXAFS spectra of $\mathrm{Cu}$ 1_ $\mathrm{N}_{2}$ measured at room temperature in air, $200{ }^{\circ} \mathrm{C}$ in $\mathrm{H}_{2}$ after reduction for 1 hour, $200{ }^{\circ} \mathrm{C}$ in $\mathrm{CO}$ and $\mathrm{O}_{2}$ (1:1) right after the reaction starts and $200{ }^{\circ} \mathrm{C}$ in $\mathrm{CO}$ and $\mathrm{O}_{2}$ after 4 hours, b) the same spectra for $\mathrm{Cu}-2 \_\mathrm{N}_{2}$; c) $\mathrm{Cu}$ K edge XANES spectra and d) magnitude of the Fourier transform of $\mathrm{k}^{2}$-weighted $\mathrm{Cu} \mathrm{K}$ edge EXAFS spectra of $\mathrm{Cu}$-2_Air measured at room temperature in air, $200{ }^{\circ} \mathrm{C}$ in $\mathrm{H}_{2}$ after reduction for 1 hour, $200{ }^{\circ} \mathrm{C}$ in $\mathrm{CO}$ and $\mathrm{O}_{2}(1: 1)$ right after the reaction starts and $200^{\circ} \mathrm{C}$ in $\mathrm{CO}$ and $\mathrm{O}_{2}$ after 4 hours. 


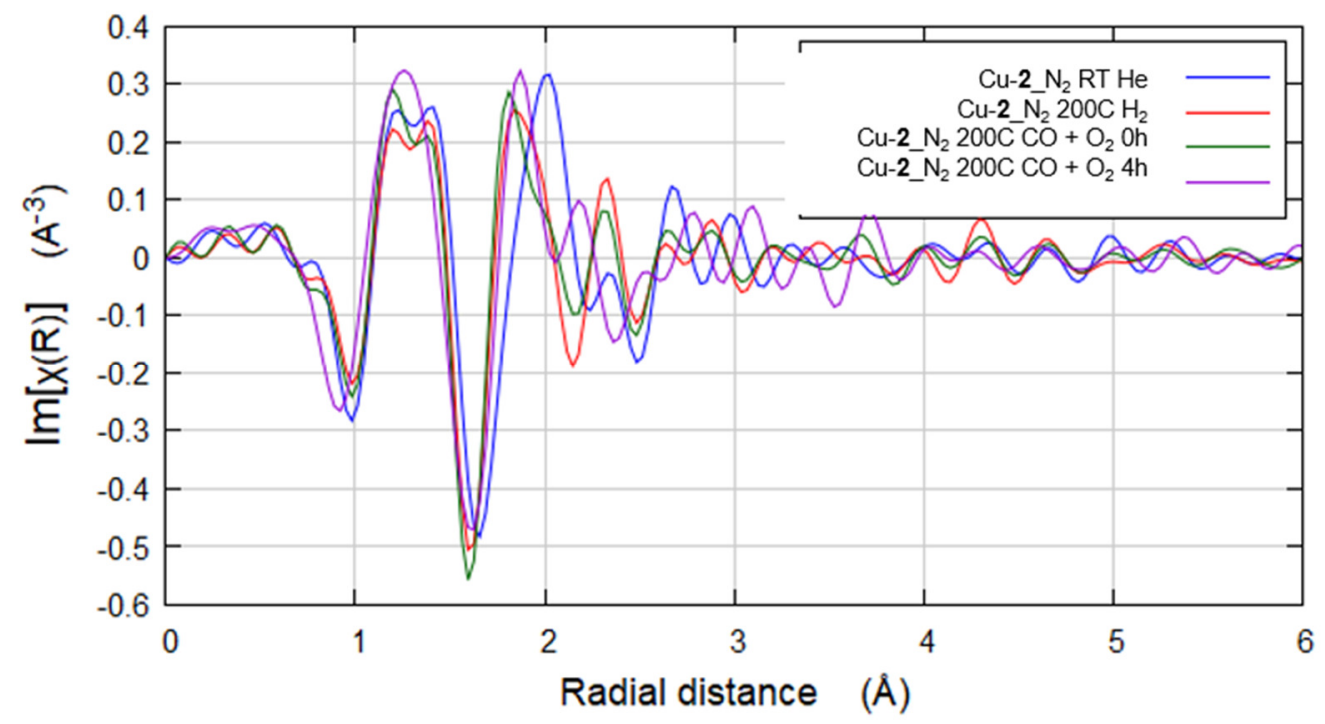

Fig. S10. Imaginary part of the Fourier transform of $\mathrm{k}^{2}$ weighted chi(k) of in situ EXAFS of the $\mathrm{Cu}-2 \_\mathrm{N}_{2}$ catalysts measured at room temperature in air, $200{ }^{\circ} \mathrm{C}$ in $\mathrm{H}_{2}$ after reduction for 1 hour, $200{ }^{\circ} \mathrm{C}$ in $\mathrm{CO}$ and $\mathrm{O}_{2}(1: 1)$. 
Table S1. Surface elemental composition in mol. \% measured from XPS survey scan.

\begin{tabular}{|c|c|c|c|c|c|}
\hline Sample & $\mathrm{C}(*)$ & $\mathrm{N}$ & $\mathrm{O}(*)$ & $\mathrm{Cu}$ & $\mathrm{Cl}$ \\
\hline IPOF-tr-te $(\mathbf{1})$ & 91 & 6.2 & 3.0 & - & - \\
\hline $\mathrm{Cu}-\mathbf{1} \_\mathrm{N}_{2}$ & 81 & 5.4 & 4.8 & 3.6 & 3.6 \\
\hline $\mathrm{Cu}-\mathbf{1} \_$Air & 70 & 2.5 & 14 & 7.4 & 2.5 \\
\hline IPOF-ph-py (2) & 85 & 12 & 3.1 & - & - \\
\hline $\mathrm{Cu}-2$-N 2 & 76 & 15 & 4.4 & 2.4 & 1.9 \\
\hline $\mathrm{Cu}$-2_Air & 71 & 8.3 & 9.1 & 5.2 & 4.9 \\
\hline
\end{tabular}

* The carbon surface concentration includes adventitious carbon. The oxygen surface concentration is significantly higher than the bulk concentration due to terminal aldehyde groups on the IPOF or also formation of oxidized copper nanoparticles. 
Table S2. The catalyst $\mathrm{Cu}$ weight loading determined by ICP and the corresponding $\mathrm{Cu}$ : $\mathrm{N}$ molar ratio.

\begin{tabular}{|c|c|c|}
\hline Sample & $\mathrm{Cu}$ (wt. \%) & $\mathrm{Cu}: \mathrm{N}$ \\
\hline $\mathrm{Cu}-1 \_\mathrm{N}_{2}$ & 18.2 & 0.30 \\
\hline Cu-1_Air & 27.6 & 0.54 \\
\hline $\mathrm{Cu}-2 \_\mathrm{N}_{2}$ & 9.7 & 0.06 \\
\hline $\mathrm{Cu}-2 \_$Air & 32.1 & 0.27 \\
\hline
\end{tabular}


Table S3. EXAFS fitting results of the fresh catalysts.

\begin{tabular}{|c|c|c|c|c|c|c|}
\hline Catalyst & $\begin{array}{c}\text { Scattering } \\
\text { Pair }\end{array}$ & $\mathrm{S}_{0}^{2}$ & $\mathrm{CN}$ & $\mathrm{R}(\AA)$ & $\Delta \mathrm{E}_{0}(\mathrm{eV})$ & $\sigma^{2}\left(\AA^{2}\right)$ \\
\hline Cu-1_Air & $\mathrm{Cu}-\mathrm{O}$ & $0.85 *$ & $3.6 \pm 0.6$ & $1.98 \pm 0.02$ & $2.6 \pm 1.4$ & $0.006 \pm 0.003$ \\
\hline Cu-2_Air & $\mathrm{Cu}-\mathrm{O}$ & $0.85 *$ & $3.0 \pm 0.3$ & $1.99 \pm 0.01$ & $3.1 \pm 1.3$ & $0.007 \pm 0.002$ \\
\hline \multirow{2}{*}{$\mathrm{Cu}-1 \_\mathrm{N}_{2}$} & $\mathrm{Cu}-\mathrm{N}$ & \multirow{2}{*}{$0.85 *$} & $0.8 \pm 0.2$ & $1.98 \pm 0.03$ & $8.1 \pm 2.9$ & $0.008 \pm 0.002$ \\
\hline & $\mathrm{Cu}-\mathrm{Cl}$ & & $1.9 \pm 0.4$ & $2.27 \pm 0.02$ & $-3.2 \pm 1.1$ & $0.008 \pm 0.003$ \\
\hline \multirow{2}{*}{$\mathrm{Cu}-2 \_\mathrm{N}_{2}$} & $\mathrm{Cu}-\mathrm{N}$ & \multirow{2}{*}{$0.85 *$} & $2.3 \pm 0.6$ & $2.02 \pm 0.04$ & $7.7 \pm 2.4$ & $0.009 \pm 0.004$ \\
\hline & $\mathrm{Cu}-\mathrm{Cl}$ & & $0.8 \pm 0.2$ & $2.24 \pm 0.02$ & $-2.7 \pm 0.8$ & $0.006 \pm 0.002$ \\
\hline
\end{tabular}

* The amplitude reduction factor $\mathrm{S}_{0}^{2}$ is fixed at the value $(0.85)$ obtained by fitting the $\mathrm{Cu}$ metal foil. 
Table S4. In situ EXAFS fitting results for $\mathrm{Cu}-\mathbf{1} \_$Air.

\begin{tabular}{|c|c|c|c|c|c|c|}
\hline Condition & $\begin{array}{c}\text { Scattering } \\
\text { Pair }\end{array}$ & $\mathrm{S}_{0}{ }^{2}$ & $\mathrm{CN}$ & $\mathrm{R}(\AA) \#$ & $\Delta \mathrm{E}_{0}(\mathrm{eV}) \#$ & $\sigma^{2}\left(\AA^{2}\right) \#$ \\
\hline $\mathrm{RT} \mathrm{He}$ & $\mathrm{Cu}-\mathrm{O}$ & $0.85 *$ & $3.6 \pm 0.6$ & $1.98 \pm 0.02$ & $2.6 \pm 1.4$ & $0.006 \pm 0.003$ \\
\hline $200{ }^{\circ} \mathrm{C} \mathrm{H}_{2}$ & $\mathrm{Cu}-\mathrm{O}$ & $0.85 *$ & $0.8 \pm 0.2$ & $1.98 \pm 0.04$ & $7.9 \pm 4.5$ & $0.005 \pm 0.002$ \\
\cline { 2 - 7 } & $\mathrm{Cu}-\mathrm{Cu}$ & $3.4 \pm 0.7$ & $2.51 \pm 0.02$ & $-3.0 \pm 3.2$ & $0.012 \pm 0.002$ \\
\hline $\begin{array}{c}200{ }^{\circ} \mathrm{C} \\
\mathrm{CO}+\mathrm{O}_{2} 0 \mathrm{~h}\end{array}$ & $\mathrm{Cu}-\mathrm{N} / \mathrm{O}$ & $0.85 *$ & $2.0 \pm 0.3$ & $1.97 \pm 0.02$ & $7.0 \pm 1.6$ & $0.008 \pm 0.003$ \\
\hline $\begin{array}{c}200{ }^{\circ} \mathrm{C} \\
\mathrm{CO}+\mathrm{O}_{2} 4 \mathrm{~h}\end{array}$ & $\mathrm{Cu}-\mathrm{N} / \mathrm{O}$ & $0.85 *$ & $2.4 \pm 0.3$ & $1.99 \pm 0.01$ & $7.8 \pm 1.3$ & $0.006 \pm 0.002$ \\
\hline
\end{tabular}

* The amplitude reduction factor $\mathrm{S}_{0}^{2}$ is fixed at the value $(0.85)$ obtained by fitting the $\mathrm{Cu}$ metal foil. 